\title{
The journal club and medical education: over one hundred years of unrecorded history
}

\author{
Mark Linzer
}

Department of Community Medicine, Mount Sinai Medical Center, New York, NY, the Department of Medicine, Montefiore Medical Center and the Albert Einstein College of Medicine, Bronx, NY and the Division of General Internal Medicine, Duke University Medical Center, Durham, NC. USA.

\begin{abstract}
Summary: Sir William Osler organized a journal club at McGill University in 1875, and several authors suggest that journal clubs were found in certain European countries (in particular, Germany and England) prior to that time. The evolution and development of the journal club, however, has not been recorded in the medical literature. Through personal communications and interviews with senior clinicians and historians, I have traced the history of the journal club as an educational modality. In the early 1900 s in Germany, journal clubs were routinely found in departments of medicine and medical schools. From 19171975, journal clubs evolved into a forum for continuing medical education. Recently, journal clubs have been designed to teach critical appraisal skills to physicians-in-training. Journal clubs are currently found in the fields of medicine, surgery, psychiatry, nursing, pharmacy, obstetrics and gynaecology, paediatrics and geriatric social service.

This powerful educational tool has played an active role in medical education for over a century. The journal club should be more formally incorporated into the medical educational curriculum.
\end{abstract}

\section{Introduction}

A journal club is a group of individuals who meet regularly to discuss critically the clinical applicability of articles in the current medical journals. While the medical journal club is commonly a part of the medical educational system, the medical literature has not detailed the rich history of this important institution. This paper represents the results of my historical search in this regard and provides the first written description of the role played by the journal club over the past 100 years.

\section{Methods}

My historical review began with a computerized literature search (Medline from 1966, Social Science Literature Index from 1972, Educational Research Information Center from 1972 and Dissertation Abstracts from 1861). This search revealed only five entries before 1975. I then reviewed the histories and

Correspondence: M. Linzer M.D. Box 3040, Duke University medical Center, Durham, NC 27710, USA.

Accepted: 20 January 1987 private manuscripts of several major European and American medical centres. I also collected data by personally interviewing and corresponding with Heads of Institutes of the History of Medicine, Emeritus Professors of Medicine, and authors of early articles on medical journal clubs.

\section{Results}

One of the first references that I could locate to a journal club as a distinct entity was Cushing's description ${ }^{1}$ of Osler's first journal club in Montreal in 1875 ('for the purchase and distribution of periodicals to which he could ill afford to subscribe as an individual'). Dr Erwin H. Ackerknecht, former Director of the Institute of the History of Medicine at Zurich, suggests that Osler probably 'heard about the journal club from somewhere else, preferably from Germany, at that time the international medical leader' (E.H. Ackerknecht, personal communication). There is also an early reference which hints at the origin of the phrase, 'journal club'. Stephen Paget, in a volume devoted to the memoirs and letters of his 
father, Sir James Paget, ${ }^{2}$ describes the situation at St. Bartholomew's Hospital in London in the period 1835-1854. The library was quite small, without a suitable reading room. Sir James noted that in place of this, some of the self-elect of the pupils, making themselves into a kind of club, had a small room over a baker's shop near the Hospital-gate where we could sit and read the journals and where some, in the evening, played cards.'

Cushing describes Osler's journal club as a fruitful experience which he 'successfully supported later on in Baltimore.' In his history of the Johns Hopkins Hospital, Chesney notes that the first journal club meeting was held there on October $29,1889 .{ }^{3}$ This journal club, held thereafter on a weekly basis, flourished for a number of years before giving way to individual departmental journal clubs. Turner adds that, during the time period 1914 to 1947, almost every department at the Johns Hopkins Medical Institutions had their own journal club 'for prompt review of the world's literature. ${ }^{4}$ These departmental journal clubs usually met on a monthly basis at members' homes in the evening, but in the 1920s and 1930s the Department of Medicine journal club had an 'open meeting' for faculty and housestaff during the regular workday.

Although not described in the medical literature, journal clubs were present and flourishing in other environs during the period 1914-1947. Dr Scott Dudley Breckenridge began a journal club in Lexington, Kentucky in 1926. Monthly meetings were held in the evenings, and election to membership was held secret. Representatives to the club were sought from all academic medical disciplines. ${ }^{5}$ Dr Edmund Pellegrino, as Chairman of the Department of Medicine at the University of Kentucky, belonged to this journal club. He notes that in smaller but sophisticated medical communities like Lexington, medical journal clubs provided opportunities for continuing education not otherwise available when travel was more difficult' (E.D. Pellegrino, personal communication).

Dr Ackerknecht, mentioned above, reports his personal experience with journal clubs in Germany from 1929-1933. He notes that the journal club (or 'Referiestag') was 'absolutely routine.' Students were supplied articles from 'German, French or English journals for reporting' (E.H. Ackerknecht, personal communication). The Beth Israel Medical Center in New York City also had a journal club which began at about the same time. Dr Sidney Leibowitz led and participated in this housestaff journal club in 1935 and for many years thereafter (S. Leibowitz, personal communication).

The literature shows almost no entries relating to medical journal clubs over the twenty years from 1947 to 1966. The First World Conference on Medical Education in $1953^{6}$ noted that medical statistics and critical appraisal of literature were taught to undergraduates, but did not describe a journal club among their list of formal educational activities. The Yale plan of medical education, described in 1954, did not mention a journal club, ${ }^{7}$ nor did Beecher and Altschule's text, Medicine at Harvard: The First Three Hundred Years. ${ }^{8}$ A comprehensive review of postgraduate medical education in the United States in 1963 describes numerous educational models, but not the journal club. ${ }^{9}$

Dr Ludwig Eichna has provided a description of journal club activities at his institutions during the 1940s and 1950s (L.W. Eichna, personal communication). Dr Eichna organized a journal club within the Department of Medicine at New York University in 1946. This club enrolled fellows and Department of Medicine faculty. Members chose what topic to present and two or three papers were discussed in an evening. A general discussion of the clinical subject matter followed each presentation. Members who attended went on to 'achieve high positions in medical schools and academic institutes.' If the journal club spread to these new settings, it is likely that $\mathrm{Dr}$ Eichna's journal club was the stimulus.

In 1962, Dr Eichna, then Chairman of the Department of Medicine at the State University of New York Downstate Medical Center, organized a journal club for medical students. Students energetically pars ticipated in 'this type of intellectual activity, awaye from formal classroom approaches.' Meaningful discussions about the clinical subjects would evolve in many directions, and the activity was very positively received by students and faculty alike.

In 1966, Professor Mattingly at the University of Exeter wrote one of the first articles which specifically discussed medical journal clubs. ${ }^{10} \mathrm{He}$ describes varying goals for different members of the staff: an introduction to the systematic use of the medical literature for junior staff, a convenient method for surveying the literature for more senior physicians. Mattingly speaks of varied formats (including the potential benefits of serving refreshments), numbers of articles reviewed per session (one to four) and frequencies of journal club meetings (weekly to monthly). He consistently refers to the need to have a 'permanent chairman' to organize the meetings. Paulley noted the benefits gained by junior housestaff from the journal club (' . . . it may be their first chance of learning to use the library') and always included them in the journal clubs which he directed at Ipswich Hospital in the early $1960 \mathrm{~s}^{11,12}$ (J.W. Paulley, personal communication).

The early 1980s produced a number of reports concerning individual experiences with different journal club formats. These newer references described the journal club as a setting in which participants could learn the critical reading skills appropriate to a deeper 
understanding of the medical literature. Inui incorporated critical reading seminars for medical residents into a morning report setting. ${ }^{13}$ Woods \& Winkel delineated four journal club formats appropriate for their residents in obstetrics and gynaecology, ${ }^{14}$ while Gehlbach and colleagues used an eight week journal club format for teaching family medicine residents to read the medical literature. ${ }^{15}$ Riegelman ${ }^{16}$ and Sackett and co-workers at McMaster University ${ }^{17}$ have refined the process of critical review of the literature, and Riegelman has suggested a specific framework for critical review that can be incorporated into a journal club format. ${ }^{18}$ Journal clubs have also been recently reported in the fields of nursing, ${ }^{19-23}$ surgery, ${ }^{24}$ pharmacy, ${ }^{25}$ psychiatry ${ }^{26,27}$ and geriatric social service. ${ }^{28}$

\section{Comment}

The journal club has had a place in the education of physicians for a very long time. Despite a paucity of recorded information, prominent medical educators on both sides of the Atlantic attest to its presence and value over the past 60 years. It is unclear whether the recent proliferation of references to journal clubs within the medical literature represents a spread in the phenomenon, a recent growth of interest in critical appraisal of medical literature or simply increased attention paid to a respected part of the educational process.

The focus of journal clubs has apparently shifted over the years. What was once a setting in which the world's current literature was surveyed became a forum for discussing clinical subjects raised by the literature and, most recently, a format for teaching critical reading skills to physicians, nurses and social workers. My colleagues and I at Montefiore Medical Center recently completed a survey of the goals and formats of the active journal clubs in medical residency programs in New York City. It is remarkable to note that all three of the historical goals of medical journal clubs (to 'keep up' with the literature, to impact on clinical practice and to teach critical reading skills) were mentioned in our survey with almost equal frequencies. ${ }^{29}$ Current journal club coordinators, without documentation to which they might refer, appear to be respecting the unwritten legacy of the journal club. While new goals have been added, the principles of Osler have been maintained.

Our survey also found that journal clubs were present in $85 \%$ of the medical residency programs in New York City. This included both university hospital and community hospital programs. If the journal club is so prevalent an educational format, then its role in contemporary medical education may be considerable. Research to evaluate and optimize this role is required.

All physicians are faced with the problem of keeping abreast of a rapidly enlarging volume of contemporary medical literature. Even in 1875, Osler recognized this problem and established a journal club to provide a solution. Since that time, the journal club has played an active role in helping physicians 'keep up' with the current literature. The journal club has recently received more attention within the medical literature as it has evolved into a setting where physicians are taught the skills for appraising critically medical articles. This increase in attention is important if we are better to evaluate and define the role that the journal club will play within the future of medical education.

\section{Acknowledgments}

I am indebted to Dr Kurt Deuschle for his encouragement with this project. I am grateful to Dr Gerald Friedland, Dr James Scheuer, Professor Bess Dana, Dr Michael Mulvihill, Dr Clyde Schechter, Dr Edward Speedling and Dr Francis A. Neelon for manuscript review. I also thank Dr Albert Lyons (Archivist, Mt Sinai Medical Center), Professor Samuel Bloom, Dr Ludwig Eichna, Dr George Harrell, Dr Edmund Pellegrino, Dr Sidney Leibowitz, Dr Erwin Ackerknecht, Professor D. Mattingly, Ms Inge DuPont, Mr Robin LeSueur, Ms Nancy McCall and Ms Sally Morganstern for assistance with my historical research, and Ms Elaine Suhr and Ms Ingrid Symes for manuscript preparation.

\section{References}

1. Cushing, H. The Life of Sir William Osler, Volume 1. Oxford University Press, Oxford, 1926, pp 132-133, 154.

2. Paget, S. Memoirs and Letters of Sir James Paget. Longmans, Green and Co., London, 1901, p42.

3. Chesney, A. The Johns Hopkins Hospital and the Johns Hopkins University School of Medicine. Johns Hopkins Press, Baltimore, 1943, p 160.

4. Turner, T.B. Heritage of Excellence: The Johns Hopkins Medical Institutions, 1914-1947 Johns Hopkins Press, Baltimore, 1974, p 253.
5. Massey, F.M. The Dudley Journal Club. 1963 (private manuscript).

6. First World Conference on Medical Education. Aims and content of the medical curriculum. $\mathrm{Br} \mathrm{Med} J$ 1953, ii: 487-488.

7. Lippard, V.W. The Yale plan of medical education after thirty years. J Med Ed 1954, 29: 17-23.

8. Beecher, H.K. \& Altschule, M.D. Medicine at Harvard: The First Three Hundred Years. University Press of New England, New Hampshire, 1977. 
9. Whitfield, A.G.W. Postgraduate medical education in the United States. Lancet 1963, ii: 514-518.

10. Mattingly, D. Journal clubs. Postgrad Med J 1966, 42: $120-122$.

11. Paulley, J.W. Continuing education in a area hospital. Postgrad Med J 1963, 39: 321.

12. Paulley, J.W. Postgraduate medical education in a provincial hospital. Postgrad Med J 1965, 41: 213-215, 218-220.

13. Inui, T.S. Critical reading seminars for medical residents. Med Care 1981, 19: 122-124.

14. Woods, J.R. \& Winkel, C.E. Journal club format emphasizing techniques of critical reading. $J$ Med $E d$ 1982, 57: 799-801.

15. Gehlbach, S.H., Bobula, J.A. \& Dickinson, J.C. Teaching residents to read the medical literature. $J$ Med $E d$ 1980, 55: 362-365.

16. Riegelman, R.K. Studying a Study and Testing a Test. How to Read the Medical Literature. Little, Brown and Company, Boston, 1981.

17. Sackett, D. Clinical Epidemiology Newsletter. Number 4. May, 1984.

18. Riegelman, R.K. Studying a study: Methods for critically reading the medical literature. SREPCIM Newsletter (Synopsis), 1984, 6: 57-58.

19. Kranstuber, S.S. Establishing a nursing journal club for professional education and certification. J Contin Educ Nurs 1982, 13: 24-27.
20. Casey, M. \& Shafer, P. The journal club: One method of developing head nurses. Nurs Manage 1982, 13: 36-37.

21. Christie, H.A. Hospital journal clubs Nurs Times 1975 , 71: 631 .

22. O'Neill, S. Journal club - RYH style. Can Nurse 1972 , 68: $43-44$.

23. Douglas, C. Journal club-Cape Breton style. Can Nurse 1972, 68: 43.

24. Mason, G.R. Journal clubs and the cost of health care. Am J Surg 1980, 140, 589-590.

25. Palmer, H.A. Journal clubs - social approach to continuing education for pharmacists. Contemp Pharm Practice 1978, 1: 34-35.

26. Summers, W.K., Rich, C.L., Kaufman, K.R. \& Sonis, W. Cholinergic influences in tardive dyskinesia journal club critique. Am J Psych 1978, 135: 621.

27. Strauss, G.D., Yager, J. \& Offer, D. Research training in psychiatry: Survey of current practices. Am J Psych 1980, 137: 727-729.

28. Blumenfield, S. Gerontology journal club: a continuing education modality for experienced social workers in an acute hospital setting. The Gerontologist 1985, 25: 11-14.

29. Linzer, M., Mercando, A. \& Hupart, K.H. Role of a medical journal club in residency training. $J$ Med $E d$ 1986, 61: 471-473. 